\title{
Circulating Antibodies to Dietary Proteins in Ulcerative Colitis
}

\author{
RALPH WRIGHT,* M.D., D.PHIL., M.R.C.P. ; S. C. TRUELOVE, * M.D., F.R.C.P.
}

Brit. med. F., 1965, 2, 142-144

In another article we have described the clinical results obtained in a controlled therapeutic trial of various diets in ulcerative colitis (Wright and Truelove, 1965). Three diets were compared: (1) a milk-free diet ; (2) a diet excluding milk and gluten ; and (3) a "dummy" diet which was essentially a normal diet. The patients were seen regularly throughout the trial period of one year for clinical and sigmoidoscopic assessment. At each attendance a sample of blood was taken for various estimations, including serological tests for circulating antibodies to several dietary proteins. The objects of this side of the study were as follows: (a) to study the effect of exclusion of these dietary items on the levels of the relevant circulating antibodies; $(b)$ to see whether the level of circulating antibodies at the beginning of the trial period bore any relation to any favourable clinical effects observed; and (c) to see whether the level of circulating antibodies showed any consistent change when a clinical relapse occurred or when the patient returned to a normal diet.

\section{Materials and Methods}

On admission to the dietary trial a specimen of blood was taken from each patient by venepuncture and the serum separated and stored at $-20^{\circ} \mathrm{C}$. A preservative was not added to the serum, but each specimen was stored in 12-18 small aliquots. No aliquot was thawed and refrozen more than three times.

Further specimens of serum were taken at each visit and stored in the same way. Since the patients were seen twice during the first month and thereafter at monthly intervals for one year, at least 14 serial specimens were available for testing from each patient with the exception of those who were withdrawn from the trial because of more than three relapses and an occasional patient who had attended irregularly. Specimens were taken at one, two, and four weeks after the reintroduction of milk or gluten into the diet, so that 20 or more specimens were available from some subjects. The maximum period of storage before testing was two years.

\section{Dietary Antigens}

Milk Proteins.-Whole cow's milk protein (spray-dried at a low temperature), and the purified proteins of cow's milk, casein, $\alpha$-lactalbumin, and $\beta$-lactoglobulin, were prepared by Dr. R. Aschaffenburg, of the National Institute for Research in Dairying, according to the method which he has described (Gunther et al., 1960). The antigens were used in a concentration of $0.5 \%$ in phosphate-saline buffer at $\mathrm{pH} 6.4$.

Gluten Fraction III.-A peptic-tryptic digest of wheat gluten (fraction III) was prepared according to the method described by Frazer et al. (1959). The lyophilized powder was usually used at a concentration of $1 \%$, but when not available a $1 / 5$ dilution of the digest was used.

Ovalbumin.-Lyophilized recrystallized ovalbumin manufactured by Messrs. L. Light and Co. Ltd. was used in a concentration of $0.5 \%$.

* Nuffield Department of Clinical Medicine, the Radcliffe Infirmary, Oxford.

\section{Immunological Tests}

Coated Tanned Red-cell Test.-The coated tanned red-cell test of Boyden (1951) as modified by Gunther et al. (1960) was used throughout. Specimens of serum were inactivated at $56^{\circ} \mathrm{C}$. for 30 minutes and serial dilutions of $1 / 10,1 / 100$, $1 / 1,000$ and $1 / 10,000$ made in glass tubes. Absorbed and heated normal rabbit serum $1 / 250$ in saline was used as diluent. All the specimens of serum from any one patient were tested simultaneously to one or more of the antigens in large batches with appropriate positive and negative controls. Sera tested in any one batch were selected so as to maintain a balance between patients in the three dietary groups. $0.1 \mathrm{ml}$. of tanned coated human group $\mathrm{O}$ red cells was added to each tube and the result read after two hours; the tubes were shaken and read again at 18 hours. The haemagglutination reaction was interpreted as negative, doubtful, one plus, or two plus.

\section{Results}

Serial specimens of serum from 51 of the 77 patients admitted to the clinical trial have been tested for antibodies to six dietary proteins.

The results were recorded on special charts on which the clinical data obtained during the trial had already been noted. It was therefore possible to see at a glance whether there was any obvious correlation between changes in antibody titre and the clinical course of the colitis.

From simple inspection of the charts the following tentative conclusions could be made: (a) antibody titres to each of the proteins bear no close relation to one another in the individual patient ; $(b)$ there is little fluctuation in antibody titre in serial specimens of serum taken over a period of a year or more from the same patient ; $(c)$ any fluctuations of titre which do occur bear no obvious relation to the nature of the diet, to remission or relapse of the colitis, or to treatment with systemic or local corticosteroids; and $(d)$ reintroduction of milk or gluten into the diet does not produce a change in antibody response.

Quantitative analysis of the data was made by relating the antibody titres of sera taken during the course of the trial to the initial reading. A rise in titre above the initial level has been recorded as + , and a fall in titre as -.

Table I shows that the antibody titre was as likely to rise as to fall, irrespective of the state of clinical remission or relapse, and that the titre was also independent of treatment with corticosteroids. Patients on a normal diet showed a slightly greater likelihood of having a rise in titre than those on a milkfree or a gluten-free plus milk-free diet, but apart from this the groups were closely similar.

When the initial antibody titres for each of the dietary proteins are related to the subsequent relapse rate in the different dietary groups there appears to be an association, but the numbers are small and the results are not significant statistically. However, when the three dietary groups are combined there is an obvious positive correlation between the initial antibody titre to whole milk and the relapse rate (Table II). Patients with an initial titre of $1 / 100$ or more to whole milk have a much greater chance of relapsing than those in whom the reaction is negative or positive at $1 / 10$ (Table IIIa). A similar 
TABLE I.-Antibody Levels During Course of Trial in Relation to Initial Level

\begin{tabular}{|c|c|c|c|c|c|c|c|c|c|c|c|c|c|c|c|c|c|c|c|}
\hline & \multicolumn{3}{|c|}{ Casein } & \multicolumn{3}{|c|}{$a$-Lactalbumin } & \multicolumn{3}{|c|}{$\beta$-Lactoglobulin } & \multicolumn{3}{|c|}{ Gluten Fraction III } & \multicolumn{3}{|c|}{ Whole Milk } & \multicolumn{3}{|c|}{ Ovalbumin } \\
\hline & & 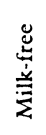 & $\begin{array}{l}\overrightarrow{\widetilde{J}} \\
\text { है } \\
\text { z }\end{array}$ & 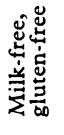 & 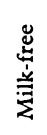 & $\begin{array}{l}\overrightarrow{\widetilde{\Xi}} \\
\text { E⿱ } \\
\text { Z }\end{array}$ & 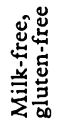 & 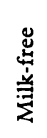 & $\begin{array}{l}\text { ] } \\
\text { Zू } \\
\text { z }\end{array}$ & 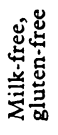 & 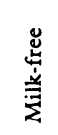 & $\begin{array}{l}\overline{\widetilde{\varpi}} \\
\text { E⿱ } \\
\text { z }\end{array}$ & 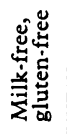 & $\begin{array}{l}\text { 岁 } \\
\text { 䇋 }\end{array}$ & 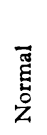 & 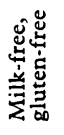 & 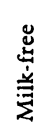 & $\begin{array}{l}\bar{\Xi} \\
\tilde{\Xi} \\
\text { Z }\end{array}$ & 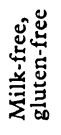 \\
\hline $\begin{array}{l}\text { Antibody levels when in re- } \\
\text { lapse and not on treatment }\end{array}$ & $\begin{array}{l}+ \\
0\end{array}$ & $\begin{array}{l}3 \\
9 \\
2\end{array}$ & $\begin{array}{l}8 \\
7 \\
7\end{array}$ & $\begin{array}{r}3 \\
10 \\
7\end{array}$ & $\begin{array}{l}1 \\
6 \\
6\end{array}$ & $\begin{array}{r}3 \\
12 \\
5\end{array}$ & $\begin{array}{r}3 \\
11 \\
7\end{array}$ & $\begin{array}{r}1 \\
12 \\
1\end{array}$ & $\begin{array}{r}1 \\
18 \\
4\end{array}$ & $\begin{array}{r}3 \\
15 \\
2\end{array}$ & $\begin{array}{r}3 \\
11 \\
0\end{array}$ & $\begin{array}{r}2 \\
14 \\
7\end{array}$ & $\begin{array}{r}3 \\
16 \\
1\end{array}$ & $\begin{array}{l}1 \\
9 \\
4\end{array}$ & $\begin{array}{r}4 \\
8 \\
11\end{array}$ & $\begin{array}{r}0 \\
11 \\
9\end{array}$ & $\begin{array}{l}3 \\
9 \\
2\end{array}$ & $\begin{array}{r}5 \\
11 \\
7\end{array}$ & $\begin{array}{r}2 \\
12 \\
3\end{array}$ \\
\hline $\begin{array}{l}\text { Antibody levels } \\
\text { treatment when on } \\
\text { corticosteroids }\end{array}$ & $\stackrel{+}{0}$ & $\begin{array}{r}12 \\
31 \\
1\end{array}$ & $\begin{array}{r}14 \\
28 \\
8\end{array}$ & $\begin{array}{r}7 \\
26 \\
13\end{array}$ & $\begin{array}{r}4 \\
28 \\
10\end{array}$ & $\begin{array}{r}9 \\
31 \\
6\end{array}$ & $\begin{array}{r}3 \\
31 \\
10\end{array}$ & $\begin{array}{r}4 \\
36 \\
5\end{array}$ & $\begin{array}{l}4 \\
36 \\
11\end{array}$ & $\begin{array}{r}3 \\
34 \\
10\end{array}$ & $\begin{array}{r}11 \\
29 \\
4\end{array}$ & $\begin{array}{r}6 \\
37 \\
7\end{array}$ & $\begin{array}{r}10 \\
33 \\
5\end{array}$ & $\begin{array}{r}5 \\
34 \\
6\end{array}$ & $\begin{array}{l}13 \\
23 \\
13\end{array}$ & $\begin{array}{r}3 \\
29 \\
14\end{array}$ & $\begin{array}{r}9 \\
26 \\
10\end{array}$ & $\begin{array}{r}9 \\
26 \\
15\end{array}$ & $\begin{array}{r}3 \\
31 \\
12\end{array}$ \\
\hline $\begin{array}{l}\text { Antibody levels when on } \\
\text { treatment with local cortico- } \\
\text { steroids only }\end{array}$ & + & $\begin{array}{r}8 \\
17 \\
1\end{array}$ & $\begin{array}{r}6 \\
14 \\
8\end{array}$ & $\begin{array}{r}5 \\
14 \\
5\end{array}$ & $\begin{array}{r}4 \\
14 \\
7\end{array}$ & $\begin{array}{r}5 \\
16 \\
5\end{array}$ & $\begin{array}{r}4 \\
13 \\
6\end{array}$ & $\begin{array}{r}1 \\
23 \\
3\end{array}$ & $\begin{array}{r}1 \\
22 \\
5\end{array}$ & $\begin{array}{r}5 \\
17 \\
2\end{array}$ & $\begin{array}{r}7 \\
18 \\
1\end{array}$ & $\begin{array}{r}1 \\
22 \\
5\end{array}$ & $\begin{array}{r}6 \\
13 \\
5\end{array}$ & $\begin{array}{r}2 \\
18 \\
6\end{array}$ & $\begin{array}{r}3 \\
12 \\
13\end{array}$ & $\begin{array}{r}1 \\
18 \\
5\end{array}$ & $\begin{array}{r}8 \\
14 \\
4\end{array}$ & $\begin{array}{r}5 \\
15 \\
8\end{array}$ & $\begin{array}{r}3 \\
14 \\
7\end{array}$ \\
\hline $\begin{array}{l}\text { Antibody levels when symp- } \\
\text { tom-free and not on treat- } \\
\text { ment }\end{array}$ & + & $\begin{array}{l}30 \\
78 \\
17\end{array}$ & $\begin{array}{l}31 \\
60 \\
14\end{array}$ & $\begin{array}{r}9 \\
81 \\
15\end{array}$ & $\begin{array}{l}12 \\
76 \\
30\end{array}$ & $\begin{array}{l}23 \\
52 \\
25\end{array}$ & $\begin{array}{r}6 \\
67 \\
20\end{array}$ & $\begin{array}{r}4 \\
98 \\
24\end{array}$ & $\begin{array}{l}11 \\
73 \\
21\end{array}$ & $\begin{array}{r}2 \\
88 \\
15\end{array}$ & $\begin{array}{l}25 \\
91 \\
9\end{array}$ & $\begin{array}{r}9 \\
82 \\
14\end{array}$ & $\begin{array}{l}15 \\
64 \\
22\end{array}$ & $\begin{array}{l}11 \\
90 \\
24\end{array}$ & $\begin{array}{l}20 \\
52 \\
33\end{array}$ & $\begin{array}{l}15 \\
73 \\
17\end{array}$ & $\begin{array}{l}31 \\
65 \\
27\end{array}$ & $\begin{array}{r}8 \\
70 \\
27\end{array}$ & $\begin{array}{r}5 \\
62 \\
38\end{array}$ \\
\hline
\end{tabular}

+ Represents a rise of titre above the initial antibody level.

- Represents no change from the initial antibody level.

TABLE II.-Initial Antibody Titres in Relation to the Relapse Rate (Combining all Dietary Groups)

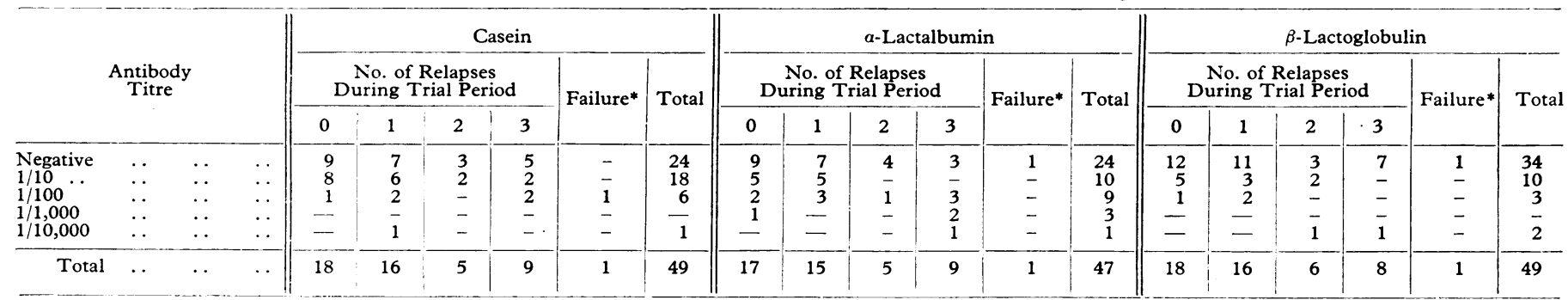

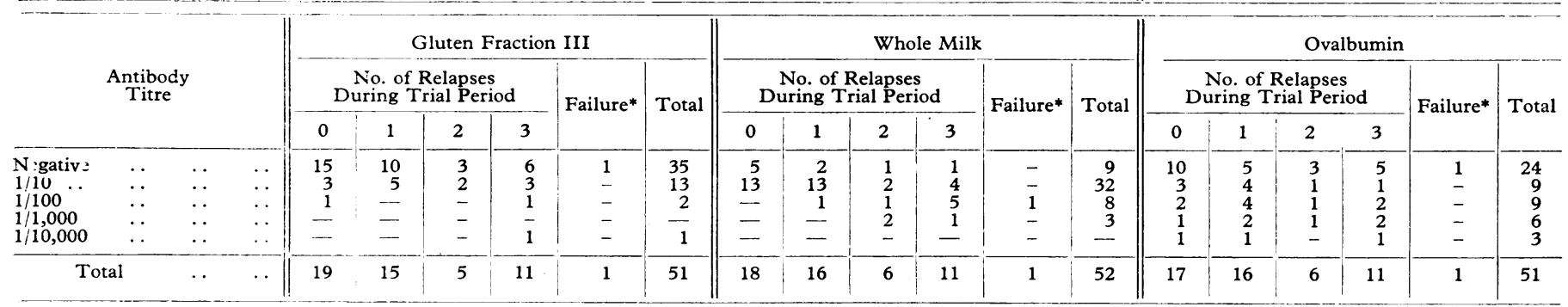

* Failure to respond to corticosteroid treatment.

correlation is seen in the case of the initial level of antibodies to $\alpha$-lactalbumin (Table IIIb), although the association is not as strong as with whole milk. There seems to be no pronounced correlation between initial antibody titre and relapse rate in the case of the other dietary proteins studied.

TABLE III.-Relation of High Initial Tiire of Antibody to Whole Milk and to $\alpha$-Lactalbumin and Subsequent Relapses During the Trial (Condensed from Data in Table II)

\begin{tabular}{|c|c|c|c|c|c|}
\hline \multirow{2}{*}{\multicolumn{2}{|c|}{$\begin{array}{c}\text { Initial } \\
\text { Antibody } \\
\text { Titre }\end{array}$}} & \multicolumn{2}{|c|}{ No. of Relapses } & \multirow{2}{*}{ Total } & \multirow{5}{*}{$\begin{array}{l}\text { With Yates's } \\
\text { correction } \\
\chi^{2} c=16 \cdot 5 \\
\mathrm{n}=1 \\
\mathrm{P}<0.001\end{array}$} \\
\hline & & Less Than 2 & 2 or More & & \\
\hline \multicolumn{5}{|c|}{ (a) For whole milk } & \\
\hline $\begin{array}{l}\text { Negative or } 1 / 10 \\
1 / 100 \text { or higher }\end{array}$ & $\because$ & $\begin{array}{r}36 \\
4\end{array}$ & $\begin{array}{l}5 \\
7\end{array}$ & $\begin{array}{l}41 \\
11\end{array}$ & \\
\hline Total & .. & 40 & 12 & 52 & \\
\hline \multicolumn{6}{|c|}{ (b) For a-lactalbumin } \\
\hline $\begin{array}{l}\text { Negative or } 1 / 10 \\
1 / 100 \text { or higher }\end{array}$ & .. & $\begin{array}{r}30 \\
7\end{array}$ & $\begin{array}{l}4 \\
6\end{array}$ & $\begin{array}{l}34 \\
13\end{array}$ & \multirow{2}{*}{$\begin{array}{c}\text { With Yates's } \\
\text { correction } \\
\chi^{2} c=4.75 \\
\text { n }=1 \\
P<0.05\end{array}$} \\
\hline Total .. & .. & 37 & 10 & 47 & \\
\hline
\end{tabular}

\section{Discussion}

The main positive finding in the present study is that patients with ulcerative colitis with a high initial titre of circulating antibodies to whole milk are much more likely to have a series of rapid relapses than are patients with low initial titres. The same is true, though to a lesser degree, as regards circulating antibodies to $\alpha$-lactalbumin. No significant association was found between initial titres and relapse rate so far as casein, $\beta$-lactoglobulin, gluten fraction III, and ovalbumin are concerned.

There are at least two possible explanations for this finding. The first is that there is some causal connexion between the antibody level and the disease. The fact that the finding applies to certain dietary antibodies and not to others is in itself in favour of some connexion between the specific items of diet and the disease. This view finds support because the particular antibodies showing the association with relapse rate are concerned with cow's milk, for which there is clinical evidence in favour of some aetiological significance. On the other hand, although the relationship can be demonstrated statistically, it does not appear to be a guide to the clinical response to a milkfree diet. This can be illustrated by the findings in five of our trial patients who all showed strong clinical evidence of being sensitive to milk. Only one of these five showed high titres of circulating antibodies to whole milk. Haemagglutinating antibodies may not be a good guide to clinical hypersensitivity in the individual patient. It is of interest that Saperstein et al. (1963), when investigating children suffering from various allergic responses to cow's milk, found that the passive cutaneous anaphylaxis test corresponded fairly closely to the clinical results, while haemagglutination tests were unreliable. However, our own limited experience with the passive cutancous anaphylaxis test in ulcerative colitis has been fruitless.

The second possibility is that a high antibody level may be a reflection of abnormal absorption of whole protein and may 
be only a measure of mucosal damage. In this connexion it is worth mentioning that the small-intestinal mucosa is frequently abnormal in ulcerative colitis, and the degree of abnormality is positively correlated with the clinical severity of the colitis (Salem et al., 1964, 1965). This raises the possibility that absorption of whole protein may occur from the small intestine, with resulting high levels of antibody that are then no more than an indication that the intestine has been widely affected, which in turn may indicate a relatively bad prognosis.

Circulating antibodies to dietary proteins are present from birth and can be demonstrated in cord blood, commonly at a higher titre than in maternal blood (Wright et al., 1962). When infants are weaned and fed on cow's milk the levels of circulating antibodies to cow's-milk proteins rise considerably (Gunther et al., 1962). In ulcerative colitis, in coeliac disease, and in idiopathic steatorrhoea the titre of circulating antibodies to various dietary proteins are often high (Taylor and Truelove, 1961; Taylor et al., 1961, 1964). So far as ulcerative colitis is concerned, early weaning from the breast was found to be twice as common in the subjects of this disease as in control subjects (Acheson and Truelove, 1961). There is the possibility that immunological stimulation by dietary proteins during infancy may set the stage for a variety of diseases in later life and that ulcerative colitis is one of them.

\section{Summary}

While making a controlled therapeutic trial of three types of diet in ulcerative colitis, the opportunity was taken to study the levels of circulating antibodies to various dietary proteins throughout the one-year trial period. Serial observations have been made on 51 of these patients, the sera being taken at monthly intervals and tested for antibodies to whole cow's milk, casein, $\alpha$-lactalbumin, $\beta$-lactoglobulin, gluten fraction III, and ovalbumin.
The titres of circulating antibodies to the various dietary proteins bore no close relationship to one another in the individual patients.

There was little fluctuation in antibody titre throughout the period of study, and the occurrence of a relapse of ulcerative colitis, the use of corticosteroids in therapy, and the exclusion or reintroduction of specific items from the diet had no consistent effect on the titres.

For the 51 patients as a group there was a highly significant association between a high titre of circulating antibodies to whole milk and multiple relapses of colitis occurring during the trial period. A similar though less pronounced relationship was also found with $\alpha$-lactalbumin.

In the individual case clinical evidence of hypersensitivity to milk could not be predicted from the antibody level.

The significance of these findings is discussed in relation to the possibility of ulcerative colitis being an allergic disease.

\section{REFERENCES}

Acheson, E. D., and Truelove, S. C. (1961). Brit. med. F., 2, 929.

Boyden, S. V. (1951) f. exp. Med., 93,107.

Frazer, A. C., Fletcher, R. F., Ross, C. A. C., Shaw, B, Sammons, H. G., and Schneider, R. (1959). Lancet, 2, 252.

Gunther, M., Aschaffenburg, R., Matthews, R. H., Parish, W. E., and Coombs, R. R. A. (1960). Immunology, 3, 296.

Cheek, E., Matthews, R. H., and Coombs, R. R. A. (1962). Int. Arch. Allergy, 21, 257.

Salem, S. N., Truelove, S. C., and Richards, W. C. D. (1964). Brit. med. F., 1, 394.

Saperstein, S., Anderson, D. W., jun., Goldman, A. S., and Kniker, W. T. (1963). Pediatrics, 32, 580 .

Taylor K. Thomson D. L., Truelove, S. C., and Wright, R. (1961) Brit. med. f., 2, 1727.

— and Truelove, S. C. (1961). Ibid., 2, 924.

Wright, R., Taylor, K. B., Truelove, S. C., and Aschaffenburg, R. (1962) Brit. med. F., 2, 513 .

and Truelove, S. C. (1965). Ibid.

\title{
Plasma Renin Concentration in Human Hypertension. 1: Relationship Between Renin, Sodium, and Potassium
}

\author{
J. J. BROWN,* M.B., B.S., B.SC., M.R.C.P. ; D. L. DAVIES, * M.B., B.S. ; \\ A. F. LEVER,* M.B., B.S., B.SC., M.R.C.P. ; J. I. S. ROBERTSON,* M.B., B.S., B.SC., M.R.C.P.
}

Brit. med. F., 1965, 2, 144-148

The demonstration by Goldblatt et al. (1934) that hypertension could be produced experimentally by renal artery constriction revived interest in the earlier observation by Tigerstedt and Bergman (1898) that the kidneys contained a substance, renin, which had a pressor effect on intravenous injection. It was later suggested that when the renal artery was narrowed renin was released from the kidney into the circulation and acted upon plasma substrate to produce the pressor peptide angiotensin, which then raised the arterial pressure by direct vasoconstrictor effect (see Braun-Menéndez et al., 1946). Goldblatt $(1947,1964)$ proposed that a similar mechanism was responsible for " essential" hypertension, in which he surmised that multiple intrarenal arterial constrictions were present, corresponding to the experimental renal artery clip.

These theories have been subject to considerable attack-see reviews by Page and Bumpus (1961) and by Pickering and Peart (1964)-largely because several workers have failed to

* Medical Unit, St. Mary's Hospital, London. demonstrate renin or ang:otensin in experimental hypertension in quantities sufficient to account for the hypertension by direct pressor effect (Blacquier et al., 1960 ; Scornik and Paladini, 1961 ; Peart et al., 1961 ; Langford, 1963).

Goldblatt (1937) showed that experimental renal hypertens:on was dependent upon an intact adrenal gland. Floyer (1951) confirmed this, and also demonstrated that renal hypertension which had been abolished by adrenalectomy could be restored by giving sodium chloride.

The subsequent proposal by Gross (1958) that the reninangiotensin system might serve to regulate aldosterone secretion revived interest in this field, since aldosterone-secreting adrenal tumours were known to cause hypertension (Conn, 1955). Subsequently, independent studies by three groups demonstrated that angiotensin infusions caused increased aldosterone production in both man and the dog (Genest et al., 1960a, 1960b; Laragh et al., 1960a ; Mulrow and Ganong, 1961). 